\title{
The roles of stem cell memory $T$ cells in hematological malignancies
}

\author{
Ling $\mathrm{Xu}^{1,2}$, Yikai Zhang ${ }^{1,2}$, Gengxin Luo ${ }^{1}$ and Yangqiu $\mathrm{Li}^{1,2,3^{*}}$
}

\begin{abstract}
Adoptive cell therapy $(\mathrm{ACT})$ is rapidly migrating from bench to clinical therapy for hematological malignancies. Recently, a new subtype of memory T cells, stem cell memory $T$ ( $\left.T_{S C M}\right)$ cells, was shown to be one of the most favorable subsets for ACT. $T_{\text {SCM }}$ has high self-renewal capacity and is associated with superior T cell engraftment, persistence, and antitumor immunity. In this review, we focused on the characteristics of antigen-specific $T_{\text {Scm }}$ cells and discussed their potential for immunotherapy targeting hematological malignancies.
\end{abstract}

Keywords: Stem cell memory T cells, Adoptive cell therapy, Hematological malignancy, Antigen-specific T cells

\section{Introduction}

$T$ cell immunodeficiencies have been observed in patients with hematological disorders [1]. These deficiencies lead to the expansion of malignant clones and are thought to play an important role in tumorigenesis [2-5]. To design an effective approach for recovering $\mathrm{T}$ cell immunity, particularly antigen-specific $\mathrm{T}$ cell immunity, it is necessary to accurately evaluate the $\mathrm{T}$ cell immune status at either the molecular or cellular level, including characteristics such as recent thymic output function, number of naive $\mathrm{T}$ cells, diversity in the $\mathrm{T}$ cell receptor (TCR) repertoire, and tumor antigen-specific cytotoxicity $\mathrm{T}$ cell clones [6-9]. More recently, stem cell memory $\mathrm{T}\left(\mathrm{T}_{\mathrm{SCM}}\right)$ cells have been described as a new immune biomarker for evaluating long-term memory $\mathrm{T}$ cell immune reconstitution, which is an important index after hematopoietic stem cell transplantation (HSCT) [10-12]. $\mathrm{T}_{\mathrm{SCM}}$ cells have been shown to be able to differentiate into central memory $\mathrm{T}$ cells $\left(\mathrm{T}_{\mathrm{CM}}\right)$, effector memory $\left(\mathrm{T}_{\mathrm{EM}}\right)$, and terminal effector $\mathrm{T}$ cells $\left(\mathrm{T}_{\mathrm{TE}}\right)$.

Adaptive immunity is characterized by the ability to form long-lived immunological memory. Memory T cells develop when antigen-specific naive $\mathrm{CD} 4^{+}$or $\mathrm{CD} 8^{+} \mathrm{T}$ cells become activated upon antigen exposure and subsequently undergo proliferative expansion and differentiation $[13,14]$. Therefore, efficient and persistent immune

\footnotetext{
* Correspondence: yangqiuli@hotmail.com

1Department of Hematology, First Affiliated Hospital, Jinan University, Guangzhou 510632, China

${ }^{2}$ Institute of Hematology, Jinan University, Guangzhou 510632, China

Full list of author information is available at the end of the article
}

memory is essential for long-term protection against infections and malignancies. Memory $\mathrm{T}$ cells play a critical role in maintaining this immune defense [15]. $\mathrm{T}_{\mathrm{SCM}}$ cells are considered as an important immune marker for the repopulating $\mathrm{T}$ cell pool and immune reconstitution which is associated with favorable clinical outcome after HSCT [16]. $\mathrm{T}_{\mathrm{SCM}}$ cell research may support the advances in biomarker research, diagnosis, and therapy for hematological malignancies [17-20]. Moreover, $\mathrm{T}_{\mathrm{SCM}}$ cell research may be important for understanding and influencing diverse chronic immune reactions, including graft-versus-host disease (GVHD) [21].

\section{$\mathrm{T}_{\mathrm{SCM}}$ cell characteristics}

Memory $\mathrm{T}$ cells (including $\mathrm{CD} 4^{+}$and $\mathrm{CD} 8^{+}$memory $\mathrm{T}$ cells) include several subtypes: stem cell memory $\left(\mathrm{T}_{\mathrm{SCM}}\right)$, central memory $\left(\mathrm{T}_{\mathrm{CM}}\right)$, transitional memory $\left(\mathrm{T}_{\mathrm{TM}}\right)$ (described only in $\mathrm{CD}^{+}$memory $\mathrm{T}$ cells), effector memory $\left(\mathrm{T}_{\mathrm{EM}}\right)$, and terminal effector $\left(\mathrm{T}_{\mathrm{TE}}\right) \mathrm{T}$ cells $[16,22]$. $\mathrm{T}_{\mathrm{SCM}}$ cells were first observed in a murine model of GVHD by Zhang et al., who reported a new subset of post-mitotic $\mathrm{CD} 44^{\mathrm{lo}}{ }^{\mathrm{C} D} 62 \mathrm{~L}^{\mathrm{hi}} \mathrm{CD} 8{ }^{+} \mathrm{T}$ cells expressing Sca-1 (stem cell antigen 1), CD122, and Bcl-2. This population of $\mathrm{T}$ cells was able to generate and sustain all allogeneic $\mathrm{T}$ cell subsets in GVHD reactions. These alloreactive $\mathrm{CD}^{+} \mathrm{T}$ cells were demonstrated to have enhanced self-renewal capacity and multipotency. These cells are capable of differentiating into $\mathrm{T}_{\mathrm{CM}}, \mathrm{T}_{\mathrm{EM}}$, and $\mathrm{T}_{\mathrm{TE}}$ cells $[14,21]$. In humans, an example came from the identification of a population of naive yellow fever (YF)-specific $\mathrm{CD}^{+} \mathrm{T}$ cells after 
vaccination. These cells were stably maintained for more than 25 years and were capable of ex vivo self-renewal. Indepth analysis of markers and genome-wide mRNA profiling have shown that these cells are distinct from genuine naive cells from unvaccinated donors and resemble the recently described stem cell-like memory subset $\mathrm{T}_{\mathrm{SCM}}$ [23]. Moreover, epigenetic analysis has also revealed that histone modifications and gene expression signatures could distinguish $\mathrm{T}_{\mathrm{SCM}}$ from other $\mathrm{CD}^{+} \mathrm{T}$ cell subsets [24]. Increasing data have supported the notion that the human $\mathrm{T}_{\mathrm{SCM}}$ subset is a clearly distinct subset in between the naive $\mathrm{T}$ cell $\left(\mathrm{T}_{\mathrm{N}}\right)$ and $\mathrm{T}_{\mathrm{CM}}$ subsets. Human $\mathrm{T}_{\mathrm{SCM}}$ cells have been described as a long-lived memory $\mathrm{T}$ cell population which are $\mathrm{CD} 45 \mathrm{RO}^{-}, \mathrm{CCR}^{+}, \mathrm{CD}^{2} 5 \mathrm{RA}^{+}, \mathrm{CD} 6 \mathrm{~L}^{+}$, $\mathrm{CD}_{2} 7^{+}, \mathrm{CD}_{2} 8^{+}$, and $\mathrm{IL}-7 \mathrm{R \alpha}^{+}$. These markers are characteristic of naive $\mathrm{T}$ cells. The immunophenotypic markers expressed in different $T$ cell subtypes (from $T_{N}$ to $T_{T E}$ cells) are summarized in Table $1 . \mathrm{T}_{\mathrm{SCM}}$ cells express increased levels of CD95, IL-2R $\beta$, CXCR3, and LFA-1 and exhibit numerous functional attributes distinct from memory cells. However, human $\mathrm{T}_{\mathrm{SCM}}$ cells constitute only approximately $2-4 \%$ of the total $\mathrm{CD} 4^{+}$and $\mathrm{CD} 8^{+} \mathrm{T}$ cell population in the periphery and can be identified by polychromatic flow cytometry based on the simultaneous expression of several naive markers together with the memory marker CD95 [25]. A linear T cell differentiation model and the minimum set of markers used for identifying and sorting $\mathrm{T}_{\mathrm{SCM}}$ are depicted in Fig. 1 [25].

Self-renewing memory $\mathrm{T}$ cells may be regulated by shared signaling pathways such as those involved in hematopoietic stem cells or memory B cells. The Wnt$\beta$-catenin pathway is an evolutionarily conserved pathway that regulates hematopoietic stem cell self-renewal and multipotency by limiting stem cell proliferation and differentiation. Similarly, a key role for Wnt signaling during the maintenance of "stemness" in $\mathrm{CD}^{+} \mathrm{T}_{\mathrm{SCM}}$ cells was demonstrated by Gattinoni et al. It was shown that disrupting the $\mathrm{Wnt} / \mathrm{\beta}$-catenin pathway by glycogen

Table 1 Summary of the expression of functional molecules in circulating naive, memory $T$ cell and terminal effector $T$ cell subsets

\begin{tabular}{|c|c|}
\hline Subset & Phenotype \\
\hline$\overline{T_{N}}$ & 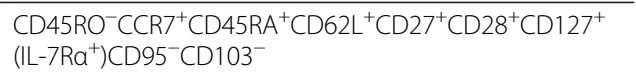 \\
\hline $\mathrm{T}_{\mathrm{SCM}}$ & $\begin{array}{l}\mathrm{CD} 45 \mathrm{RO}^{-} \mathrm{CCR} 7^{+} \mathrm{CD} 45 \mathrm{RA}^{+} \mathrm{CD} 62 \mathrm{~L}^{+} \mathrm{CD} 27^{+} \mathrm{CD} 28^{+} \mathrm{CD} 127^{+} \\
\left(\left(\mathrm{L}-7 \mathrm{Ra}^{+}\right) \mathrm{CD}^{+} 5^{+} \mathrm{CD} 03^{-}\right.\end{array}$ \\
\hline $\mathrm{T}_{C M}$ & $\begin{array}{l}\mathrm{CD} 45 \mathrm{RO}^{+} \mathrm{CCR} 7^{+} \mathrm{CD} 45 \mathrm{RA}^{-} \mathrm{CD} 2 \mathrm{~L}^{+} \mathrm{CD} 28^{+} \mathrm{CD} 27^{+} \mathrm{CD} 127^{+} \\
\left(\left(\mathrm{L}-7 \mathrm{Ra}^{+}\right) \mathrm{CD}^{+} 5^{+} \mathrm{CD} 103^{-}\right.\end{array}$ \\
\hline $\mathrm{T}_{\mathrm{EM}}$ & $\begin{array}{l}\mathrm{CD} 45 \mathrm{RO}^{+} \mathrm{CCR} 7^{-} \mathrm{CD} 45 \mathrm{RA}^{-} \mathrm{CD}_{22} \mathrm{~L}^{-} \mathrm{CD} 28^{-/+} \mathrm{CD}_{27}{ }^{-/+} \mathrm{CD} 127^{-/+} \\
\left(\mathrm{IL}-7 \mathrm{Ra}^{-/+}\right) \mathrm{CD} 95^{+} \mathrm{CD} 103^{+}\end{array}$ \\
\hline $\mathrm{T}_{\mathrm{TE}}$ & $\begin{array}{l}\mathrm{CD} 45 \mathrm{RO}^{-} \mathrm{CCR}^{-} \mathrm{CD} 45 \mathrm{RA}^{+} \mathrm{CD} 62 \mathrm{~L}^{-} \mathrm{CD} 28^{-/+} \mathrm{CD}_{27} \mathrm{CD}^{-} 127^{-} \\
\left(\mathrm{IL}-7 \mathrm{Ra}^{-}\right) \mathrm{CD}^{-} 5^{+} \mathrm{CD}_{103^{-}}\end{array}$ \\
\hline
\end{tabular}

"+" positive expression, "-" negative expression, $T_{N}$ naive T cell, $T_{S C M}$ stem cell memory T cell, $T_{C M}$ central memory T cell, $T_{E M}$ effector memory T cell, $T_{T E}$ terminal effector $T$ cell synthase-3 3 (GSK-3 $\beta$ ) inhibitors promoted the generation of $\mathrm{CD} 44^{\text {low }} \mathrm{CD} 62 \mathrm{~L}^{\text {high }} \mathrm{Sca}-1^{\text {high }} \mathrm{CD} 122^{\text {high }} \mathrm{Bcl}-2^{\text {high }}$ self-renewing multipotent $\mathrm{CD} 8^{+} \mathrm{T}_{\mathrm{SCM}}$ cells with proliferative and antitumor capacities that exceeded those of the $\mathrm{T}_{\mathrm{CM}}$ and $\mathrm{T}_{\mathrm{EM}}$ subsets $[11,26,27]$. In addition, antigen-specific $\mathrm{T}_{\mathrm{SCM}}$ cells were shown to preferentially reside in the lymph nodes (LNs) and less so in the spleen and bone marrow [28].

There are numerous factors that act as modulators regulating the maturation and activation of $\mathrm{CD} 8^{+} \mathrm{T}$ cells, for example, suppressor of cytokine signaling (SOCS) is one of the key modulators [29]. Moreover, it has been reported that activation of naive $\mathrm{T}$ cells with anti-CD3 and antiCD28 antibody-conjugated beads in the presence of low doses of IL-7 and IL-15 promotes the generation of CD45RA ${ }^{+} \mathrm{CD}^{-} 2 \mathrm{~L}^{+} \mathrm{CCR}^{+} \mathrm{CD}^{+} 5^{+} \mathrm{T}_{\mathrm{SCM}}$ cells [30].

\section{Antigen-specific $\mathbf{T}_{\mathrm{SCM}}$}

It is well known that antigen-specific $\mathrm{T}$ cells are crucial components for antitumor or antivirus immunity in patients with hematological malignancies, particularly in patients after HSCT. It is possible that the number of antigen-specific $\mathrm{T}_{\mathrm{SCM}}$ cells may be the determining factor of immunity. However, there have been few reports on antigen-specific $\mathrm{T}_{\mathrm{SCM}}$ cells. Low frequency of these cells limits detailed characterization. For example, $<1 \%$ of total human $\mathrm{T}$ cells are defined as $\mathrm{CD} 8^{+} \mathrm{CD} 45 \mathrm{RA}$ ${ }^{+} \mathrm{CCR} 7{ }^{+} \mathrm{CD} 127^{+} \mathrm{CD} 95^{+}$viral-specific $\mathrm{T}_{\mathrm{SCM}}$ cells. Human $\mathrm{CMV}$-specific $\mathrm{T}_{\mathrm{SCM}}$ cells can be detected at frequencies similar to those observed in other subsets, with frequency around $\sim 1 / 10,000 \mathrm{~T}$ cells $[31,32]$.

Antigen-specific $\mathrm{T}_{\mathrm{SCM}}$ cells represent a long-lasting component of the cellular immune response to viruses and tumor-associated antigens (TAAs). For virus-specific $\mathrm{T}_{\mathrm{SCM}}$ cells, research has first focused on human immunodeficiency virus type 1 (HIV-1)-specific $\mathrm{CD}^{+} \mathrm{T}_{\mathrm{SCM}}$ cells. It is known that HIV-specific $\mathrm{CD}^{+} \mathrm{T}$ cells can influence HIV-1 disease progression during untreated HIV-1 infections, and recent data have shown that HIV-1-specific $\mathrm{CD}^{+} \mathrm{T}_{\mathrm{SCM}}$ cells are detectable in all stages of HIV-1 infection. These cells were found to be increased in number in patients receiving suppressive antiretroviral therapy when compared with those untreated patients [33]. It was found that $\mathrm{CD} 4^{+} \mathrm{T}_{\mathrm{SCM}}$ cells were susceptible to HIV infection; thus, HIV-1 virus may exploit the stem cell characteristics of cellular immune memory $\mathrm{T}$ cells and lead to long-term viral persistence [34]. Similar findings were demonstrated in a study of human $\mathrm{T}$ cell leukemia virus type 1 (HTLV-1)-infected $\mathrm{CD}^{+}{ }^{+} \mathrm{T}_{\mathrm{SCM}}$ cells in patients with adult $\mathrm{T}$ cell leukemia (ATL). This report first demonstrated an association between $\mathrm{T}$ cell malignancy and $\mathrm{T}_{\mathrm{SCM}}$ cells. $\mathrm{T}_{\mathrm{SCM}}$ cells from ATL patients were capable of sustaining themselves in a less proliferative mode, yet they were able to differentiate into other memory $\mathrm{T}$ cell 


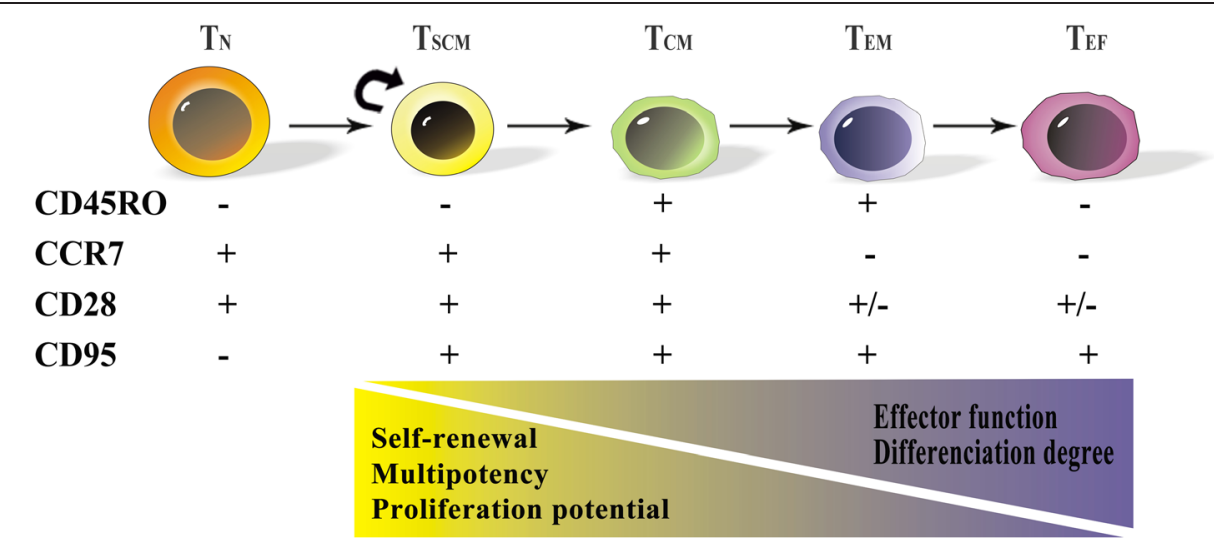

Fig. 1 Schematic model for T cell differentiation. Upon activation, naive T cells differentiate into various memory and effector cells. Self-renewal capacity, multipotency, and proliferation potential decrease upon differentiation. The expression of CD45R0, CCR7, CD28, and CD95 markers changes during $T$ cell differentiation from $T_{N}$ to $T_{T E}$. The minimum set of canonical markers can be used to identify the five major subsets of $T$ cells. $T_{N}$ naive $T$ cell, $T_{S C M}$ stem cell memory $T$ cell, $T_{C M}$ central memory $T$ cell, $T_{E M}$ effector memory $T$ cell, $T_{T E}$ terminal effector $T$ cell

populations during the rapidly propagating phase. These cells have been identified at the hierarchical apex capable of reconstituting identical ATL clones [35]. A decrease in the infection of $\mathrm{CD} 4^{+} \mathrm{T}_{\mathrm{SCM}}$ cells was found to preserve $\mathrm{CD} 4^{+} \mathrm{T}$ cell homeostasis and prevents disease progression despite significant viremia in both HIV-1 and HTLV-1 infections [36].

$\mathrm{T}_{\mathrm{SCM}}$ cells may play a major role in specific antitumor response and long-term immune surveillance directed against tumors $[17,37,38]$. In addition, $\mathrm{T}_{\mathrm{SCM}}$ cells have been proposed to be one of the key determinants of immune memory. It may be interesting to monitor the level of $\mathrm{T}_{\mathrm{SCM}}$ cells and its significance for immune reconstitution and prognosis of patients with hematological malignancies before and after therapy, particularly HSCT. There have been only a few studies on TAA-specific $\mathrm{T}_{\mathrm{SCM}}$ cells. Recently, dynamic changes of $\mathrm{T}_{\mathrm{SCM}}$ cells were longitudinally tracked in patients who underwent haploidentical HSCT. These studies demonstrated that donor-derived $\mathrm{T}_{\mathrm{SCM}}$ cells were highly enriched early after HSCT. $\mathrm{T}_{\mathrm{SCM}}$ cells can differentiate directly from naive precursors infused in the grafts. Through $\mathrm{T}$ cell receptor (TCR) gene analysis, $\mathrm{T}_{\mathrm{SCM}}$ cells have been found to have diversification in immune memory after allogeneic HSCT [10]. It was also demonstrated that the level of $\mathrm{T}_{\mathrm{SCM}}$ cells may be used to evaluate immune reconstitution in patients who received posttransplant cyclophosphamide (pt-Cy) for GVHD prophylaxis. Similarly, donor-derived $\mathrm{T}_{\mathrm{SCM}}$ cells were found to be the most abundant circulating $\mathrm{T}$ cell population in the early days following haploidentical HSCT and pt-Cy. These donor-derived $\mathrm{T}_{\mathrm{SCM}}$ cells preceded the expansion of effector cells. Antigen-specific $\mathrm{T}_{\mathrm{SCM}}$ cells generated detectable recall responses; thus, it has been proposed to explore $\mathrm{T}_{\mathrm{SCM}}$ cells derived from donor naive precursor cells in the clinical setting to overcome immunodeficiency [12]. With the ability to expand and differentiate into effectors capable of mediating potent xenogeneic GVHD in immunodeficient mice, these donor naive precursor-derived $\mathrm{T}_{\mathrm{SCM}}$ cells were noted to be superior to other memory lymphocytes. Furthermore, genemodified $\mathrm{T}_{\mathrm{SCM}}$ cells were found to be the only $\mathrm{T}$ cell subset capable of expanding and mediating GVHD in serial transplantations [30]. These findings indicate negative aspects of $\mathrm{T}_{\mathrm{SCM}}$ cells for clinical application.

\section{The potential of $\mathrm{T}_{\mathrm{SCM}}$ cells in immunotherapy for hematological malignancies}

$\mathrm{T}_{\mathrm{SCM}}$ cells may be a novel and critical therapeutic resource because these cells have the potential to serve as a stable cellular vehicle. Two gene therapy clinical trials with gene-corrected hematopoietic stem cells provided a glimpse into this possibility. Long-term in vivo $\mathrm{T}$ cell reconstitution was characterized in these trials. Specifically, the investigators traced the fate of greater than 1700 individual $\mathrm{T}$ cell clones in patients who underwent gene therapy. The studies demonstrated that the $\mathrm{T}_{\mathrm{SCM}}$ cells persisted and preserved their precursor potential in humans for up to 12 years after the infusion of genecorrected stem cells [39]. The demonstration of the safe, functional, and decade-long survival of the engineered $\mathrm{T}_{\mathrm{SCM}}$ cells in humans sets the stage for their clinical application. Since $\mathrm{T}_{\mathrm{SCM}}$ cells were shown to be capable of reconstituting the full repertoire of memory and effector $\mathrm{T}$ cells after HSCT, it is particularly attractive to use them for adoptive immunotherapies. $\mathrm{T}_{\mathrm{SCM}}$ cells might overcome current limitations, such as inefficient $\mathrm{T}$ cell engraftment, poor persistence, and inability to mediate prolonged immune attacks $[10-12,40]$.

Even though potent antitumor activity of $\mathrm{T}_{\mathrm{SCM}}$ cells was demonstrated in preclinical animal tumor models $[26,27]$, it is currently not feasible to treat patients with naturally occurring $\mathrm{T}_{\mathrm{SCM}}$ cells because it is a scarce and 
small proportion of circulating lymphocytes. Therefore, strategies that can generate, expand, and enable the redirection of $\mathrm{T}_{\mathrm{SCM}}$ cells against cancer cells need to be defined. Cieri and colleagues have recently described that a large number of $\mathrm{T}_{\mathrm{SCM}}$ cells were generated by priming T cells with low doses of IL-7 and IL-15. It is therefore possible to generate, expand, and genetically engineer $\mathrm{T}_{\mathrm{SCM}}$ cells in vitro from naive precursors. Furthermore, the in vitro-generated $\mathrm{T}_{\mathrm{SCM}}$ cells displayed enhanced proliferative capacity upon adoptive transfer into immunodeficient mice, a finding consistent with those using naturally occurring $\mathrm{T}_{\mathrm{SCM}}$ cells $[11,30]$. $\mathrm{T}_{\mathrm{SCM}}$ cells were also expanded from naive precursors by inhibiting Akt signaling during ex vivo priming and expansion. The Akt-inhibited minor histocompatibility antigen (MiHA)-specific $\mathrm{CD}^{+} \mathrm{T}$ cells had superior expansion capacity in vitro and induced superior antitumor activity in multiple myeloma-bearing immunodeficient mice. These findings provided a rationale for clinically exploiting ex vivo-generated, Akt-inhibited, MiHA-specific $\mathrm{CD}^{+} \mathrm{T}$ cells or TAA-specific $\mathrm{CD} 8^{+} \mathrm{T}$ cells for adoptive immunotherapy [41, 42]. Schmueck-Henneresse et al. also described a simplified culture protocol allowing for fast expansion of virus-specific $\mathrm{T}_{\mathrm{SCM}}$ cells from a mixed $\mathrm{T}_{\mathrm{N}} / \mathrm{T}_{\mathrm{SCM}}$ pool of peripheral blood lymphocytes. This may be the basis for novel cell therapeutic options for life-threatening viral infections [31]. Among the known memory $\mathrm{T}$ cell subpopulations, the $\mathrm{T}_{\mathrm{SCM}}$ cell subset has profound implications for the design and development of effective vaccines as well as $\mathrm{T}$ cell-based therapies $[13,26,28]$. As immunotherapy plays increasingly important roles in cancer management, further exploration of $\mathrm{T}_{\mathrm{SCM}}$ cells and their regulation may facilitate clinical development of humoral (monoclonal antibodies and inhibitors of $\mathrm{B}$ cell receptor signaling) and cellular (CART) immunotherapies [40, 43-47].

\section{Conclusions and future perspectives}

$\mathrm{T}_{\mathrm{SCM}}$ cells have the capacities of self-renewal and differentiation into various memory/effector subsets. These cells can lead to superior immune reconstitution. The identification of human $\mathrm{T}_{\mathrm{SCM}}$ cells is directly relevant for evaluating life-long cellular immune status, immune reconstitution after allogeneic HSCT, and design of vaccines and $\mathrm{T}$ cell immunotherapy. However, it remains unclear at this time whether the number of $\mathrm{T}_{\mathrm{SCM}}$ cells may be used as a standard biomarker for immune reconstitution after HSCT. In addition, the low number of $\mathrm{T}_{\mathrm{SCM}}$ cells in circulating lymphocytes is also limiting their application [11]. Strategies for in vitro and in vivo isolation and generation of highly effective antitumor $\mathrm{T}_{\mathrm{SCM}}$ cells are under intensive investigation.

\section{Abbreviations}

ACT: adoptive cell therapy; ATL: adult T cell leukemia; HTLV-1: human-cell leukemia virus type 1; MiHAs: minor histocompatibility antigens; TAA-CTL: tumor antigen associated cytotoxic T lymphocytes; $T_{\text {CM: }}$ : central memory T cell; TCR: T cell receptor; $T_{E M}$ : effector memory $T$ cell ; $T_{N}$ : naive T cell; $T_{\text {SCM: }}$ stem cell memory T cell; $T_{T E}$ : terminal effector T cell;

$\mathrm{T}_{\mathrm{TM}}$ : transitional memory $\mathrm{T}$ cell.

\section{Competing interests}

The authors declare no conflicts of interest.

\section{Authors' contributions}

The concept of this paper was devised by YQL. LX, YKZ, GXL, and YQL contributed to the intellectual input of the paper. YKZ and LX contributed to the figure preparation. All authors read and approved the final manuscript.

\section{Acknowledgements}

This study was supported by grants from the National Natural Science Foundation of China (No. 81270604), the collaborated grant for HK-Macao-TW of the Ministry of Science and Technology (2012DFH30060), the Guangdong Natural Science Foundation (No. S2013020012863), the Foundation for HighLevel Talents in Higher Education of Guangdong, China (No. [2013]246-54), the Guangzhou Science and Technology Project Foundation (No. 201510010211), and Jinan University's Scientific Research Creativeness Cultivation Project for Outstanding Undergraduates Recommended for Postgraduate Study.

\section{Author details}

${ }^{1}$ Department of Hematology, First Affiliated Hospital, Jinan University, Guangzhou 510632, China. ${ }^{2}$ Institute of Hematology, Jinan University, Guangzhou 510632, China. ${ }^{3}$ Key Laboratory for Regenerative Medicine of Ministry of Education, Jinan University, Guangzhou 510632, China.

Received: 6 August 2015 Accepted: 1 October 2015

Published online: 14 October 2015

\section{References}

1. Ji X, Zhang L, Peng J, Hou M. T cell immune abnormalities in immune thrombocytopenia. J Hematol Oncol. 2014;7:72.

2. Muller-Schmah C, Solari L, Weis R, Pfeifer D, Scheibenbogen C, Trepel M, et al. Immune response as a possible mechanism of long-lasting disease control in spontaneous remission of MLL/AF9-positive acute myeloid leukemia. Ann Hematol. 2012;91:27-32.

3. Isidori A, Salvestrini V, Ciciarello M, Loscocco F, Visani G, Parisi S, et al. The role of the immunosuppressive microenvironment in acute myeloid leukemia development and treatment. Expert Rev Hematol. 2014;7:807-18.

4. Li Y. T-cell immune suppression in patients with hematologic malignancies: clinical implications. Int J Hematol Oncol. 2014;3:289-97.

5. Shi L, Chen S, Yang L, Li Y. The role of PD-1 and PD-L1 in T-cell immune suppression in patients with hematological malignancies. J Hematol Oncol. 2013;6:74.

6. Li Y, Yin Q, Yang L, Chen S, Geng S, Wu X, et al. Reduced levels of recent thymic emigrants in acute myeloid leukemia patients. Cancer Immunol Immunother. 2009;58:1047-55.

7. Chen S, Huang X, Zheng H, Geng S, Wu X, Yang L, et al. The evolution of malignant and reactive gammadelta $+\mathrm{T}$ cell clones in a relapse T-ALL case after allogeneic stem cell transplantation. Mol Cancer. 2013;12:73.

8. Chen S, Zha X, Yang L, Li B, Liye Z, Li Y. Deficiency of CD3gamma, delta, epsilon, and zeta expression in T cells from AML patients. Hematology. 2011;16:31-6.

9. Shi L, Chen S, Zha X, Xu Y, Xu L, Yang L, et al. Enhancement of the TCRzeta expression, polyclonal expansion, and activation of $\mathrm{T}$ cells from patients with acute myeloid leukemia after IL-2, IL-7, and IL-12 induction. DNA Cell Biol. 2015;34:481-8.

10. Cieri N, Oliveira G, Greco R, Forcato M, Taccioli C, Cianciotti B, et al. Generation of human memory stem T cells after haploidentical T-replete hematopoietic stem cell transplantation. Blood. 2015;125:2865-74.

11. Gattinoni L, Restifo NP. Moving T memory stem cells to the clinic. Blood. 2013;121:567-8.

12. Roberto A, Castagna L, Zanon V, Bramanti S, Crocchiolo R, McLaren JE, et al. Role of naive-derived T memory stem cells in T-cell reconstitution following allogeneic transplantation. Blood. 2015;125:2855-64. 
13. Restifo NP, Gattinoni L. Lineage relationship of effector and memory T cells. Curr Opin Immunol. 2013;25:556-63.

14. Chahroudi A, Silvestri G, Lichterfeld M. T memory stem cells and HIV: a long-term relationship. Curr HIV/AIDS Rep. 2015;12:33-40.

15. Crotty $S$, Ahmed R. Immunological memory in humans. Semin Immunol. 2004;16:197-203

16. Mateus J, Lasso P, Pavia P, Rosas F, Roa N, Valencia-Hernandez CA, et al. Low frequency of circulating CD8+ T stem cell memory cells in chronic chagasic patients with severe forms of the disease. PLoS Negl Trop Dis. 2015;9:e3432.

17. Darlak KA, Wang Y, Li JM, Harris WA, Giver CR, Huang C, et al. Host bone marrow-derived IL-12 enhances donor T cell engraftment in a mouse model of bone marrow transplantation. J Hematol Oncol. 2014;7:16.

18. Wang L, Xiao H, Zhang X, Wang $C$, Huang $H$. The role of telomeres and telomerase in hematologic malignancies and hematopoietic stem cell transplantation. J Hematol Oncol. 2014;7:61.

19. Tibes R, Mesa RA. Targeting hedgehog signaling in myelofibrosis and other hematologic malignancies. J Hematol Oncol. 2014;7:18.

20. Smith AD, Roda D, Yap TA. Strategies for modern biomarker and drug development in oncology. J Hematol Oncol. 2014;7:70.

21. Zhang $Y$, Joe G, Hexner E, Zhu J, Emerson SG. Host-reactive CD8+ memory stem cells in graft-versus-host disease. Nat Med. 2005;11:1299-305.

22. Takeshita M, Suzuki K, Kassai Y, Takiguchi M, Nakayama Y, Otomo Y, et al. Polarization diversity of human CD4(+) stem cell memory T cells. Clin Immunol. 2015;159:107-17.

23. Fuertes Marraco SA, Soneson C, Cagnon L, Gannon PO, Allard M, Abed Maillard S, et al. Long-lasting stem cell-like memory CD8+ T cells with a naive-like profile upon yellow fever vaccination. Sci Transl Med. 2015;7:282ra248

24. Crompton JG, Narayanan M, Cuddapah S, Roychoudhuri R, Ji Y, Yang W, et al. Lineage relationship of CD8 T cell subsets is revealed by progressive changes in the epigenetic landscape. Cell Mol Immunol 2015;doi:10.1038/ cmi.2015.032.

25. Mahnke YD, Brodie TM, Sallusto F, Roederer M, Lugli E. The who's who of T-cell differentiation: human memory T-cell subsets. Eur J Immunol. 2013:43:2797-809.

26. Gattinoni L, Lugli E, Ji Y, Pos Z, Paulos CM, Quigley MF, et al. A human memory T cell subset with stem cell-like properties. Nat Med. 2011:17:1290-7.

27. Gattinoni L, Zhong XS, Palmer DC, Ji Y, Hinrichs CS, Yu Z, et al. Wnt signaling arrests effector $T$ cell differentiation and generates CD8+ memory stem cells. Nat Med. 2009;15:808-13.

28. Lugli E, Dominguez MH, Gattinoni L, Chattopadhyay PK, Bolton DL, Song K, et al. Superior T memory stem cell persistence supports long-lived T cell memory. J Clin Invest. 2013;123:594-9.

29. Palmer DC, Restifo NP. Suppressors of cytokine signaling (SOCS) in T cell differentiation, maturation, and function. Trends Immunol. 2009;30:592-602.

30. Cieri N, Camisa B, Cocchiarella F, Forcato M, Oliveira G, Provasi E, et al. IL-7 and IL-15 instruct the generation of human memory stem $T$ cells from naive precursors. Blood. 2013;121:573-84.

31. Schmueck-Henneresse M, Sharaf R, Vogt K, Weist BJ, Landwehr-Kenzel S, Fuehrer $\mathrm{H}$, et al. Peripheral blood-derived virus-specific memory stem T cells mature to functional effector memory subsets with self-renewal potency. J Immunol. 2015:194:5559-67.

32. Di Benedetto S, Derhovanessian E, Steinhagen-Thiessen E, Goldeck D, Muller L, Pawelec G. Impact of age, sex and CMV-infection on peripheral T cell phenotypes: results from the Berlin BASE-II Study. Biogerontology. 2015;16:631-43.

33. Vigano S, Negron J, Ouyang Z, Rosenberg ES, Walker BD, Lichterfeld M, et al. Prolonged antiretroviral therapy preserves HIV-1-specific CD8 T cells with stem cell-like properties. J Virol. 2015;89:7829-40.

34. Buzon MJ, Martin-Gayo E, Pereyra F, Ouyang Z, Sun H, Li JZ, et al. Long-term antiretroviral treatment initiated at primary HIV-1 infection affects the size, composition, and decay kinetics of the reservoir of HIV-1-infected CD4 T cells. J Virol. 2014;88:10056-65.

35. Nagai Y, Kawahara M, Hishizawa M, Shimazu Y, Sugino N, Fujii S, et al. T memory stem cells are the hierarchical apex of adult T-cell leukemia. Blood. 2015;125:3527-35.

36. Klatt NR, Bosinger SE, Peck M, Richert-Spuhler LE, Heigele A, Gile JP, et al. Limited HIV infection of central memory and stem cell memory CD4+ T cells is associated with lack of progression in viremic individuals. PLoS Pathog. 2014;10:e1004345.
37. Coulie PG, Van den Eynde BJ, van der Bruggen P, Boon T. Tumour antigens recognized by $T$ lymphocytes: at the core of cancer immunotherapy. Nat Rev Cancer. 2014;14:135-46.

38. Martin PJ. Reversing CD8+ T-cell exhaustion with DLI. Blood. 2014;123:1289-90

39. Biasco L, Scala S, Basso Ricci L, Dionisio F, Baricordi C, Calabria A, et al. In vivo tracking of T cells in humans unveils decade-long survival and activity of genetically modified T memory stem cells. Sci Transl Med. 2015;7:273ra213.

40. Han EQ, Li XL, Wang CR, Li TF, Han SY. Chimeric antigen receptorengineered $T$ cells for cancer immunotherapy: progress and challenges. J Hematol Oncol. 2013;6:47.

41. van der Waart AB, van de Weem NM, Maas F, Kramer CS, Kester MG, Falkenburg $\mathrm{JH}$, et al. Inhibition of Akt signaling promotes the generation of superior tumor-reactive T cells for adoptive immunotherapy. Blood. 2014;124:3490-500.

42. van der Waart AB, Hobo W, Dolstra H. Time to Akt: superior tumor-reactive T cells for adoptive immunotherapy. Oncoimmunology. 2015;4:e1003016.

43. Akinleye A, Avvaru P, Furqan M, Song Y, Liu D. Phosphatidylinositol 3-kinase (PI3K) inhibitors as cancer therapeutics. J Hematol Oncol. 2013;6:88.

44. Breton CS, Nahimana A, Aubry D, Macoin J, Moretti $P$, Bertschinger M, et al A novel anti-CD19 monoclonal antibody (GBR 401) with high killing activity against B cell malignancies. J Hematol Oncol. 2014;7:33.

45. Akinleye A, Chen Y, Mukhi N, Song Y, Liu D. Ibrutinib and novel BTK inhibitors in clinical development. J Hematol Oncol. 2013;6:59.

46. Novero A, Ravella PM, Chen Y, Dous G, Liu D. Ibrutinib for B cell malignancies. Exp Hematol Oncol. 2014;3:4

47. Suresh T, Lee LX, Joshi J, Barta SK. New antibody approaches to lymphoma therapy. J Hematol Oncol. 2014;7:58.

\section{Submit your next manuscript to BioMed Central and take full advantage of:}

- Convenient online submission

- Thorough peer review

- No space constraints or color figure charges

- Immediate publication on acceptance

- Inclusion in PubMed, CAS, Scopus and Google Scholar

- Research which is freely available for redistribution 